\title{
Differentiation of Stem Cells into Insulin-Producing Cells: Current Status and Challenges
}

\author{
Marta Pokrywczynska $\cdot$ Sandra Krzyzanowska $\cdot$ \\ Arkadiusz Jundzill · Jan Adamowicz • \\ Tomasz Drewa
}

Received: 1 June 2012/ Accepted: 20 December 2012/Published online: 3 January 2013

(C) L. Hirszfeld Institute of Immunology and Experimental Therapy, Wroclaw, Poland 2012

\begin{abstract}
Diabetes mellitus is one of the most serious public health challenges of the twenty-first century. Allogenic islet transplantation is an efficient therapy for type 1 diabetes. However, immune rejection, side effects of immunosuppressive treatment as well as lack of sufficient donor organs limits its potential. In recent years, several promising approaches for generation of new pancreatic $\beta$ cells have been developed. This review provides an overview of current status of pancreatic and extra-pancreatic stem cells differentiation into insulin-producing cells and the possible application of these cells for diabetes treatment. The PubMed database was searched for English language articles published between 2001 and 2012, using the keyword combinations: diabetes mellitus, differentiation, insulin-producing cells, stem cells.
\end{abstract}

Keywords Diabetes mellitus - Differentiation · Insulin-producing cells $\cdot$ Stem cells

\section{Introduction}

Diabetes mellitus (DM) is a chronic disease affecting nearly 350 million people worldwide. DM is classified into two major types (American Diabetes Association 2011).

M. Pokrywczynska ( $₫)$ - S. Krzyzanowska · A. Jundzill ·

J. Adamowicz · T. Drewa

Department of Tissue Engineering, Ludwik Rydygier Medical College in Bydgoszcz, Nicolaus Copernicus University in Torun,

Karlowicza 24, 85-092 Bydgoszcz, Poland

e-mail: marta.pokrywczynska@interia.pl

T. Drewa

Department of Urology, Nicolaus Copernicus Hospital,

Torun, Poland
Type 1 diabetes mellitus (DM1) results from autoimmune destruction of insulin-producing $\beta$ cells (Noguchi 2009). DM1 is responsible for approximately $10 \%$ of all DM cases. Patients with DM1 require a long-life treatment with regular insulin injections. Type 2 diabetes mellitus (DM2) is a heterogenous metabolic disorder, characterized by both insulin resistance and relative insulin deficiency. This type is responsible for more than $80 \%$ of DM cases (Raslova 2010). The first main treatment for DM2 includes proper diet and physical exercises.

There are a lot of studies indicating new methods of treatment for patients with DM1. Currently, pancreas or islet transplantation is considered as the best therapeutic option for brittle type 1 diabetes. However, the low availability of organ donors limits the number of transplants which could be performed. Alternative source of insulinproducing cells could be zoonotic islets, but it creates a lot of problems, like increased risk of graft rejection or viruses transmission. Therefore, scientists are wondering whether stem cells could differentiate into insulin-producing ones. A number of studies indicated that it is possible. This opens up new possibilities for treating patients who can get their own autologous stem cells for therapy and avoid problems associated with allo or xenotransplants.

Different types of stem cells were investigated to determine which of them would be most useful in the treatment of type 1 diabetes. Although stem cells were isolated from pancreatic ducts, islets and exocrine tissue the $\beta$-cell progenitors have not been identified (Baeyens et al. 2005; Carlotti et al. 2010; Gao et al. 2003; Soria et al. 2005). Interestingly, $\beta$ cells mass increases in vivo significantly after injury and during metabolic demand for example pregnancy or obesity. Thus, it does seem that there is a regeneration of pancreatic $\beta$ cells, but it is not clear whether it happens by self-replication or neogenesis 
(Dor et al. 2004). However, it should be emphasized that progenitor cells isolated from diseased pancreas carry a high risk of dysfunction. Therefore, there is great need for a new sources of cells to generate insulin-producing cells (IPCs). Here, we review the strategies that have been applied to the generation of IPCs from stem cells.

\section{Pancreas Development}

Generation of IPCs in vitro requires understanding how $\beta$ cells are formed in vivo. Pancreas development is a complex process guided by numerous cascades of signaling pathways and transcription factors that regulate cell differentiation. Diffusible factors secreted from surrounding tissues as well as cell-cell and cell-matrix interactions play a critical role in this process. During embryonic development, the pancreatic primordium is derived from definitive endoderm that subsequently gives rise to the primitive gut and posterior foregut. At this stage, formation of the pancreatic anlage is guided by retinoid signaling and depends on inhibition of hedgehog signaling (Lau et al. 2006; Stafford and Prince 2002; Stafford et al. 2004). The developing pancreas is consists of epithelial progenitors expressing: Pdxl (Ipf1), Hnf6 (Onecut), Hlxb9, Ptfla and $N k x 6-1$ that will give rise to endocrine, exocrine and ductal cells ( $\mathrm{Gu}$ et al. 2002; Wilson et al. 2003). Further differentiation of pancreatic epithelium is regulated by signals from the adjacent mesenchyme, such as Fgf10 (Gittes 2009). Endocrine cell specification occurs by inhibition of Notch signaling and expression of the proendocrine gene Neurog3 (Ngn3) in some of the pancreatic epithelial cells (Wilson et al. 2003). Ngn3 triggers the expression of several transcription factors: $\mathrm{Nkx2}-2$, Neurod1, Nkx6-1, Pax-4, Pax-6 and Isl1 that controls endocrine cell differentiation. Nascent endocrine cells migrate from the branched epithelium into surrounding mesenchyme and form the islets of Langerhans (Gittes 2009; Guo and Hebrok 2009). Main transcription factors involved in pancreas development are presented in Table 1.

Differentiation of stem cells to $\beta$ cells in vitro cannot be achieved in a single step, but requires a series of transition steps replicating pancreatic organogenesis. Stem cells can undergo differentiation through genetic manipulation as well as epigenetic influences from media containing the differentiating factors. Differentiating factors used to specific cell type differentiation are shown in Tables 2, 3 .

\section{Differentiation of Embryonic Stem Cells}

Numerous studies have been performed to generate insulinproducing cells through differentiation of embryonic stem cells (ESCs). ESCs are cells derived from the inner cell

Table 1 Main transcription factors involved in pancreas development

\begin{tabular}{|c|c|c|c|}
\hline Transcription factors & Abbreviation & Function & References \\
\hline $\begin{array}{l}\text { NK2 transcription factor related, } \\
\text { locus } 2\end{array}$ & Nkx2.2 & $\begin{array}{l}\text { Pancreatic endocrine development and } \\
\text { differentiation into pancreatic } \beta \text { cells }\end{array}$ & $\begin{array}{l}\text { Henseleit et al. (2005); Shiroi et al. } \\
\text { (2005) }\end{array}$ \\
\hline $\begin{array}{l}\text { NK6 transcription factor related, } \\
\text { locus } 6\end{array}$ & Nkx6.1 & Final differentiation of $\beta$ cells & $\begin{array}{l}\text { Henseleit et al. (2005); Wang et al. } \\
\text { (2011) }\end{array}$ \\
\hline Neurogenin 3 & Ngn3 & $\begin{array}{l}\text { Formation of pancreatic endocrine precursors, } \\
\text { differentiation of pancreatic precursor cells } \\
\text { towards endocrine lineages }\end{array}$ & $\begin{array}{l}\text { Habener et al. (2005); Kubo et al. } \\
\text { (2011); Liang et al. (2011) }\end{array}$ \\
\hline Paired box gene 4 & $\operatorname{Pax} 4$ & $\begin{array}{l}\text { Formation of } \beta \text { cells and } \delta \text { cells, represses glucagon } \\
\text { transcription }\end{array}$ & Collombat et al. (2005) \\
\hline Paired box gene 6 & Pax6 & $\begin{array}{l}\text { Formation of } \alpha \text { cells, activates glucagon } \\
\text { transcription }\end{array}$ & Lorenzo et al. (2011) \\
\hline Neurogenic differentiation & NeuroD & $\begin{array}{l}\text { Differentiation and islet growth, endocrine } \\
\text { differentiation in pancreatic progenitors }\end{array}$ & Artner et al. (2010) \\
\hline $\begin{array}{l}\text { Avian musculoaponeurotic } \\
\text { fibrosarcoma oncogene homolog }\end{array}$ & MafA & Controls and activates insulin gene expression & $\begin{array}{l}\text { Artner et al. (2010); Kataoka et al. } \\
\quad(2002)\end{array}$ \\
\hline $\begin{array}{l}\text { Avian musculoaponeurotic } \\
\quad \text { fibrosarcoma oncogene homolog }\end{array}$ & MafB & $\begin{array}{l}\text { Formation of } \alpha \text { cells and } \beta \text { cells, activates genes } \\
\text { involved in mature endocrine function, including } \\
\text { those significant to glucose sensing, vesicle } \\
\text { maturation, } \mathrm{Ca}^{2+} \text { signaling, and insulin secretion }\end{array}$ & Artner et al. (2006, 2010) \\
\hline Pancreatic and duodenal homeobox & $\begin{array}{l}\mathrm{Pdx}-1 / \mathrm{Ipf}-1 \\
\quad \text { (in human) }\end{array}$ & $\begin{array}{l}\text { Early pancreatic development, formation of } \beta \text { cells } \\
\text { and } \delta \text { cells, formation of exocrine tissue, } \\
\text { important activator of insulin }\end{array}$ & $\begin{array}{l}\text { Hui and Perfetti (2002); Kubo } \\
\text { et al. (2011) }\end{array}$ \\
\hline Islet-1 & Isl-1 & Early endocrine cell differentiation & May (2010) \\
\hline Forkhead box A3 & FoxA3 & Endodermal marker, differentiation of pancreas & Hori et al. (2005) \\
\hline
\end{tabular}


Table 2 Differentiation factors and cell types

\begin{tabular}{|c|c|c|}
\hline Cell type & Differentiation factors & References \\
\hline Embryonic stem cells & $\begin{array}{l}\text { B27, nicotinamide, insulin, transferin, selenium, FN, } \\
\text { exendin-4, LY294002, activin-A, LAM, RA, } \\
\text { GLP-1, Nodal, IDE1, IDE2, FGF-10, } \\
\text { cyclopamine, extendin-4, DAPT }\end{array}$ & $\begin{array}{l}\text { Bai et al. (2005); Boyd et al. (2008); Cho et al. } \\
\text { (2008); D'Amour et al. (2006); Hori et al. (2002); } \\
\text { Kroon et al. (2008); Shi et al. (2005) }\end{array}$ \\
\hline BM-MSCs & $\begin{array}{l}\text { Activin-A, conophyline, BTC- } \delta 4 \text {, BTC, } \\
\text { nicotinamide, L-glutamine, FN, LAM, HGF, } \\
\text { extendin- } 4\end{array}$ & $\begin{array}{l}\text { Hisanaga et al. (2008); Lin et al. (2010); Sun et al. } \\
\text { (2007) }\end{array}$ \\
\hline Umbilical cord blood derived MSCs & $\begin{array}{l}\text { Glucose, RA, nicotinamide, epidermal growth } \\
\text { factor, exendin-4, B27 }\end{array}$ & Chao et al. (2008); Gao et al. (2008) \\
\hline Adipose tissue-derived MSCs & $\begin{array}{l}\text { Glucose, nicotinamide, activin-A, exendin- } 4 \text {, } \\
\text { HGF, pentagastrin, BTC }\end{array}$ & Timper et al. (2006) \\
\hline Progenitor cells & $\begin{array}{l}\text { Glucose, poly-L-ornithine, FN, apo-transferin, } \\
\text { L-glutamine, RA, nicotinamide, insulin-like } \\
\text { growth factor, matrigel, FGFR2IIIb, HGF, EGF }\end{array}$ & $\begin{array}{l}\text { Elghazi et al. (2002); Feng et al. (2005); Gao et al. } \\
\text { (2003); Hori et al. (2005); Suzuki et al. (2002) }\end{array}$ \\
\hline
\end{tabular}

$D A P T$ N-[N-(3,5-difluorophenacetyl)-L-alanyl]-s-phenylglycine t-butyl ester, $R A$ retinoic acid, $B T C$ - $\delta 4$ betacellulin-delta4, $F N$ fibronectin, $L A M$ laminin, $H G F$ hepatocyte growth factor, $E G F$ epidermal growth factor

Table 3 Extrinsic factors promoting $\beta$-cell proliferation and differentiation

\begin{tabular}{|c|c|c|c|}
\hline Extrinsic factors & Abbreviation & Function & References \\
\hline Glucagon like peptide & GLP-1 & $\begin{array}{l}\text { The most potent stimulator of oral glucose-induced } \\
\text { insulin secretion, GLP-1 is released in response to } \\
\text { meal intake and is rapidly metabolized and } \\
\text { inactivated by dipeptidyl-peptidase- } 4\end{array}$ & Bai et al. (2005); Hardikar et al. (2002) \\
\hline Betacellulin & BTC & $\begin{array}{l}\text { Plays an important role in regulating growth and } \\
\text { differentiation of pancreatic } \beta \text { cells }\end{array}$ & $\begin{array}{l}\text { Cho et al. (2008); Li et al. (2004); Oh et al. } \\
\text { (2011); Shi et al. (2005); Sun et al. (2007) }\end{array}$ \\
\hline Activin-A & & Regulates neogenesis of $\beta$ cells in vivo & $\begin{array}{l}\text { Li et al. (2004); Shi et al. (2005); Sun et al. } \\
\text { (2007) }\end{array}$ \\
\hline Hepatocyte growth factor & HGF & $\begin{array}{l}\text { Promotes } \beta \text {-cell proliferation and regeneration, } \\
\text { regulates the pancreatic islet differentiation }\end{array}$ & Wang et al. (2004) \\
\hline Endothelial growth factor & EGF & Promotes the proliferation of nestin-positive cells & $\begin{array}{l}\text { Kelly et al. (2005); Schwindt et al. (2009); } \\
\text { Tureyen et al. (2005) }\end{array}$ \\
\hline $\begin{array}{l}\text { Basic fibroblast growth } \\
\text { factor }\end{array}$ & bFGF & Promotes the proliferation of nestin-positive cells & $\begin{array}{l}\text { Kelly et al. (2005); Schwindt et al. (2009); } \\
\text { Tureyen et al. (2005) }\end{array}$ \\
\hline Nicotinamide & & $\begin{array}{l}\text { Promotes formation of fetal porcine islet-like cell } \\
\text { clusters and increases the rates of proinsulin } \\
\text { biosynthesis in these clusters }\end{array}$ & Cho et al. (2008); Tang et al. (2004) \\
\hline$\beta$-mercaptoethanol & & Increases the potency of nicotinamide & Chen et al. (2004) \\
\hline Laminin & LAM & $\begin{array}{l}\text { Affects } \beta \text { cells differentiation, proliferation, and } \\
\text { insulin secretion }\end{array}$ & Lin et al. (2010) \\
\hline Fibronectin & $\mathrm{FN}$ & $\begin{array}{l}\text { Affects } \beta \text { cells differentiation, proliferation, and } \\
\text { insulin secretion }\end{array}$ & Lin et al. (2010) \\
\hline Extendin 4 & & Promotes growth and maturation of $\beta$ cells & Degn et al. (2004) \\
\hline
\end{tabular}

mass of the blastocyst, an early stage embryo. ESCs demonstrate the capacity for differentiation into cells of all three primary germ layers (ectoderm, mesoderm and endoderm) (Wobus and Boheler 2005). Given this capacity ESCs can differentiate into any desired cell types, including $\beta$ cells. Another advantage of ESCs is unlimited selfrenewal capacity, allowing generate large number of cells for therapeutic purposes. However, directed differentiation of ESCs toward specific cell types, such as IPCs is a challenge, because it requires inhibition of the formation of unwanted cell fates. Another limitation of undifferentiated ESCs is potency of post-transplantation teratoma formation. More recently, it has been shown that transplantation of differentiated ESCs also lead to teratoma formation (Boyd et al. 2008). Moreover, using human ESCs for this purpose raises many ethical and religious dilemmas.

Numerous multi-step protocols have been used to differentiate of ESCs toward the pancreatic lineage. Primary 
research resulted in the production of cells that had some $\beta$ cell characteristics, but fell short of being true fully developed cells. Currently, there are two main approach for differentiation of ESCs into IPCs: embryoid body formation and definitive endoderm formation.

The protocols involving embryonic body formation comprises two phases: the embryoid body stage (4-5 days) and the differentiation stage (30-40 days). Boyd et al. (2008) compared three different protocols to differentiate ESCs into IPCs using the embryoid body formation strategy. This study indicated that the IPCs generated using Blyszczuk protocol (Blyszczuk et al. 2004) exhibited superior C-peptide expression and longer normoglycemic rescue in diabetic mice when compared with the Hori's and Lumelsky's protocols (Hori et al. 2002; Lumelsky et al. 2001). In protocol described by Blyszczuk the ESCs were cultured in "handing drops" and in suspension for 5 days to form embryoid bodies. Then, embryoid bodies were plated in Iscove medium supplemented with $20 \%$ fetal calf serum (FCS), L-glutamine, non-essential amino acids and $\alpha$-monothioglycerol and cultured for 9 days for differentiation into cells representing derivatives of all three primary germ layers. In the next step, cells were re-plated onto poly-L-ornithine/laminin-coated culture dishes into a pancreatic differentiation medium ( $\mathrm{N} 2$ medium supplemented with progesterone, putrescine, laminin (LAM), insulin, sodium selenite, nicotinamide, transferrin, fibronectin (FN), B27 media supplement, $15 \%$ FCS) and cultured for 19 days (Blyszczuk et al. 2004). The Lumelsky's protocol involves serum-free ITSFn medium and basic fibroblast growth factor (bFGF) treatments (Lumelsky et al. 2001). The Hori's protocol involves additionally treatment of differentiating cells with PI3 kinase inhibitor LY294002, but excludes B27 supplement (Hori et al. 2002). Real-time polymerase chain reaction and immunofluorescence techniques indicated that each of these protocols lead to differentiation of ESCs toward pancreatic lineage. Although Boyd et al. (2008) showed that IPCs generated by each of this protocols released insulin in response to low glucose concentration, but did not release insulin at higher glucose concentration. This observation suggests that IPCs may also be malfunctioning in their glucose-sensing capacity in vivo. The potential of IPCs generated from ESCs using embryoid body approach to normalize glucose in streptozotocin-induced diabetes mice is very low. Several reports indicated transient correction of blood glucose level after IPCs transplantation (Blyszczuk et al. 2003; Hori et al. 2002; Lumelsky et al. 2001). This may be due to cell dying or dedifferentiation of transplanted IPCs. Another problem regarding the ESCs differentiation into IPCs using embryoid body strategy is teratoma formation (Blyszczuk et al. 2003; Hori et al. 2002; Boyd et al. 2008). A possible explanation for such a finding may be that IPCs are in fact a heterogenous mixture of undifferentiated ESCs, IPCs and even differentiated cells of other lineages.

Employing knowledge of pancreatic development in ESCs differentiation strategies lead to striking success in IPCs generation. It has been reported that using five-stage protocol that mimics pancreatic organogenesis and comprise the sequential phases of inducing a definitive endoderm, primitive gut tube, posterior foregut, pancreatic endoderm and cells that express endocrine hormones, successfully converts ESCs to IPCs (D'Amour et al. 2006). The first step in differentiation of ESCs into IPCs is formation of definitive endoderm. Two signaling pathways, the Wnt and transforming growth factor (TGF)- $\beta$ are crucial to induce formation of the definitive endoderm. Differentiation of ESCs into definitive endoderm can be achieved via treatment with activin-A and Wnt3a and confirmed by expression of endodermal markers, including SOX17, FOXA2, GATA4, CXCR4, and cerberus (D'Amour et al. 2006; Kroon et al. 2008). Nodal, CHIR99021, IDE1 and IDE2 are another molecules that induce development of the definitive endoderm (Borowiak et al. 2009; Takenaga et al. 2007). The next step after formation of definitive endoderm is induction of primitive gut tube. Removing the activin-A and adding the FGF10 and cyclopamine to the differentiation media lead to induction of transcription factors $H N F 4 \alpha$ and $H F N 1 \beta$, genes generally expressed in developing gut tube. The addition of cyclopamine, a plant alkaloid inhibits Hedgehog signaling pathway and promotes pancreatic development. The next step is reproduce the formation of the posterior foregut. It could be reached by inhibition of the Hedgehog signaling pathway and simultaneously induction of retinoic acid (RA) signaling. In this stage cyclopamine and FGF10 are maintained and RA is added. Upon addition of RA cells began express high levels of PDX1, HLXB9 and HNF6, markers of posterior foregut (D'Amour et al. 2006). During stage 4, posterior foregut differentiates towards pancreatic endoderm and endocrine precursors. The addition of $\mathrm{N}-[\mathrm{N}-(3,5-$ difluorophenacetyl)-L-alanyl]-S-phenylglycine t-butyl ester (DAPT), a $\gamma$-secretase inhibitor that blocks Notch signaling, and extendin-4 lead to expression of NKX6-1,NGN3, PAX4, and $N K X 2-2$ markers of endocrine precursors. Finally, during stage five precursor cells are differentiated into hormone expressing cells. In this stage extendin- 4 is maintained, IGF1 and hepatocyte growth factor (HGF) are added. After $\sim 2$ weeks of differentiation cells expressing each of five pancreatic endocrine hormone are detected. Many cells express more than one hormone. However, the percentage of insulin-positive cells generated using this protocol is relatively low around $7 \%$ of total cell population. Moreover C-peptide release by these cells is marginal in response to glucose (D'Amour et al. 2006). More recently the same group reported more efficient strategy to 
differentiate ESCs into IPCs. This new protocol consists of four stages instated of fives and requires only 12 days of differentiation. In brief, during first stage (definitive endoderm formation) ESCs are treated with activin-A and Wnt3a for 1 day followed by activin-A treatment alone for 2 days. In the second stage (primitive gut tube formation), cyclopamine treatment is eliminated and keratinocyte growth factor is substituted for FGF10 for 3 days. In the next stage (posterior foregut formation), differentiating cells are treated with B27, KAAD-cyclopamine, all-trans RA and Noggin instead of FGF10. In the fourth stage (pancreatic endoderm formation), cells are cultured in the absence of all factors except B27 for 3 days. Pancreatic endoderm grafted into immunodeficient mice matures in vivo for several months leading to the generation of glucose responsive insulin secreting cells (Kroon et al. 2008). The question is in what way the immature endocrine cells implanted into heterotopic environment, such as the epididymal fat pads, subcutaneous tissue or under kidney capsule differentiate into pancreatic cells.

Jiang et al. (2007a) differentiated ESCs into IPCs using four-stage protocol. In the first stage, ESCs were differentiated into definitive endoderm via treatment with sodium butyrate and activin-A for 7 days. In the second stage, the endoderm cells were differentiated into the pancreatic endoderm in medium supplemented with B27, bFGF, epidermal growth factor (EGF) and noggin for 14 days. The noggin was used to enhance PDX-1 expression. In the third stage, the pancreatic endoderm cells were differentiated into pancreatic endocrine/exocrine cells. The bFGF was removed and cells were cultured in medium supplemented with B27, EGF and noggin for 7 days. In the final, fourth stage cells were transferred into maturation medium containing nicotinamide and IGF2 and cultured for 5 days and without IGF2 for another 2 days to generate IPCs. Flow cytometric analysis indicated that only about $4 \%$ of cells were positive for C-peptide (Jiang et al. 2007a).

Despite significant improvements in novel approaches for generation of IPCs from ESCs, the final yield of IPCs is still very low (0.8-7.3\% of the final heterogenous cell population) (D'Amour et al. 2006; Jiang et al. 2007a). In addition, the amount of insulin secreted by IPCs is significantly lower as compared to native $\beta$ cells. The advances in studies on ESCs differentiation using definitive endoderm formation strategy are encouraging, but requires further investigations.

Another interesting way to generate IPCs is nuclear reprogramming. As described above, $\beta$-cell differentiation depends on cascade of transcription factors that function in an exquisitely coordinated temporal and spatial manner in the developing pancreas. The nuclear reprogramming has been used to induce the expression of critical transcription factor and guide differentiation of ESCs into IPCs. Shiroi et al. (2005) used murine ESCs transfected with $N k x 2.2$ gene to find out whether they are able to differentiate into IPCs in vitro. $N k x 2.2$ is NK-homeodomain gene expressed in pancreatic progenitor cells. $N k x 2.2$ expression is required for pancreatic endocrine development and differentiation of $\beta$ cells (Table 2) (Henseleit et al. 2005; Lin et al. 2007; Shiroi et al. 2005). This study suggested that $N k x 2.2$ promotes differentiation of ESCs into IPCs (Shiroi et al. 2005). Kubo et al. (2011) reported that the overexpression of $P d x-1$ and Ngn3 enhanced pancreatic differentiation. $P d x-1$ is involved in early pancreatic development. Ngn3 is engaged in the formation of pancreatic endocrine precursors (Table 1). Induced overexpression of $P d x-1$ led to upregulation of insulin and other pancreatic genes. These studies demonstrated that genetic engineering may be an important tool in generation of insulin-producing cells. However, forced expression of transcription factors at non-physiological level on at inappropriate time points can lead to generation of other than $\beta$-cell types or even non-pancreatic cell types (Bernardo et al. 2009; Johansson et al. 2007).

\section{Differentiation of Induced Pluripotent Stem Cells}

Induced pluripotent stem (iPS) cells are somatic cells that have been reprogrammed to an embryonic stem like-cell state by introducing genes (like OCT4, SOX2, c-MYC, KLF4 or others) important for maintaining the essential properties of ESCs (Cai et al. 2011). iPS cells have been generated from human somatic cells, like fibroblasts, peripheral blood cells, keratinocytes, neural stem cells and others (Aasen et al. 2008; Kim et al. 2009; Loh et al. 2009; Lowry et al. 2008; Park et al. 2008; Takahashi et al. 2007; $\mathrm{Yu}$ et al. 2007). These cells may provide an alternative source of stem cells for the treatment of type I diabetes. Unfortunately, genetic manipulation used to generate iPS cells can cause unexpected effects in activation of oncogens, such as c-MYC and lead to cancer formation. In addition, the viral vectors after integration with the host may lead to unexpected genetic disorder (Okita et al. 2007; Takahashi et al. 2007; Tateishi et al. 2008; Yu et al. 2009). Therefore, new and improved methods of generating iPS cells, including minimal or no genetic modification are needed (Huangfu et al. 2008; Kaji et al. 2009; Okita et al. 2008; Stadtfeld et al. 2008; Woltjen et al. 2009; Yu et al. 2009; Zhou et al. 2009).

Tateishi et al. (2008) reported that iPS cells derived from human skin fibroblast by retroviral expression of OCT4, SOX2, $c-M Y C$, and KLF4 have the potential to differentiate into insulin-producing islet-like clusters (ILCs). They indicated that iPS cells and ESCs exhibit similar morphological and genetic changes during ILCs 
differentiation. Differentiation of ILCs was performed according to four-stage protocol described previously by Jiang et al. (2007b). The iPS-derived ILCs contained C-peptide-positive and glucagon-positive cells and released $\mathrm{C}$-peptide upon glucose stimulation. Although the level of insulin secreted by iPS-derived ILCs in response to high glucose was significantly lower compared to ESCs-derived ILCs (Tateishi et al. 2008).

A highly efficient step-wise pancreatic differentiation strategy was proposed by Zhang et al. (2009a). iPS cells were generated by transducing the lentivirus containing $O C T-4, S O X 2$ and KLF4 into human fibroblasts. In the first stage human iPS cells were incubated with medium supplemented with basal serum albumin (BSA), B27, N2, activin-A and wortmannin for 4 days. In the second stage the cells were treated with medium supplemented with BSA, ITS, B27, RA, FGF-7 and NOGGIN for 4 days. In the third stage the cells were cultured in the medium with high glucose supplemented with BSA, N2, ITS and EGF for 5 days. In the final fourth stage the cells were incubated in medium with ITS, bFGF, nicotinamide, exendin-4 and BMP4. IPCs obtained by this approach expressed most of the crucial $\beta$ cells transcription factors and functional markers like: PDX1, MAFA, NKX6.1, NEUROD, ISL-1 and GLUT2. The cells co-expressed C-peptide, $P D X 1, N K X 6.1$ and $M A F A$ as is characteristic for mature $\beta$ cells (Zhang et al. 2009a).

Kunisada et al. (2012) indicated that iPS cells treatment with activin-A and a GSK3 $\beta$ inhibitor enhanced efficient endodermal differentiation, and then combined treatment with RA, a bone morphogenic protein inhibitor, and a TGF- $\beta$ inhibitor induced efficient differentiation of pancreatic progenitor cells from definitive endoderm. They also found that forskolin, dexamethasone, and a TGF- $\beta$ inhibitor induced the differentiation of insulin-producing cells from pancreatic progenitor cells. In this study 8-16.9\% of the cells became insulin positive (Kunisada et al. 2012).

\section{Differentiation of Mesenchymal Stem Cells}

A number of studies reporting differentiation of mesenchymal stem cells (MSCs) into insulin-producing cells (Chen et al. 2004; Tang et al. 2004). MSCs were isolated from many organs and tissues, such as bone marrow, fat tissue, umbilical cord blood, pancreas etc. (Hisanaga et al. 2008; Sun et al. 2007; Zhang et al. 2009b). Mesenchymal stem cells are a heterogeneous population of cells capable to multidirectional differentiation (Ding et al. 2011). MSCs can be isolated from a diabetic patient, differentiated into insulin-producing cells and then transplanted back. Using MSCs do not raise ethical and religious problems.
Differentiation of Bone Marrow Mesenchymal Stem Cells

A simple method to induce differentiation of murine bone marrow MSCs to insulin-producing cells was presented by Hisanaga et al. (2008). To induce bone marrow mesenchymal stem cells (BM-MSCs) differentiation into pancreatic endocrine cells, the cells were cultured in the basic medium in the presence of activin-A, conophylline and betacellulin- $\delta 4$ (Table 3 ). Insulin- containing secretory granules were observed in differentiated cells but the morphology of the granules was different compared to granules found in $\beta$ cells. Differentiated cells secreted mature insulin and responded to glucose stimulation in vitro. When these cells were transplanted to diabetic mice, they markedly reduced the glucose concentration (Hisanaga et al. 2008). Sun et al. (2007) reported that BMMSCs can be differentiated into IPCs by a three-stage protocol. In the first stage MSCs were cultured in serumfree high glucose medium supplemented with $\beta$-mercaptoethanol. Cell treatment with bFGF, EGF, B27 and NEAA resulted in expression of nestin, $P D X-1, N G N 3, P A X 4$, insulin and glucagon (Table 1). Then, addition of $\beta$-cellulin, activin A, B27 and nicotinamide enhanced expression of $P D X-1$ and generated cells expressing endocrine hormones including insulin and glucagon. The differentiated cells secreted insulin depending on glucose concentration (Sun et al. 2007). Zhang et al. (2010) demonstrated that BM-MSCs derived from a human first-trimester abortus can differentiate into pancreatic islet-like cell clusters following a four-step induction. Differentiation media contains: $\beta$-mercaptoethanol, bFGF, EGF, B27, HGF, nicotinamide, extendin- $4, \beta$-cellulin and zinc acetate. Differentiated cells expressed a broad gene profile related to pancreatic islet $\beta$-cell development. Immunofluorescence assay indicated that nestin was strongly expressed after second stage, NGN3, PDX1, NEUROD1, and MAFA were expressed after third stage and insulin and $C$-peptide after fourth stage (Table 1). Islet-like cell cluster released high levels of insulin and C-peptide in response to glucose stimulation in vitro. Transplantation of islet-like cell cluster to streptozotocine-induce diabetic mice returned normoglycemia (Zhang et al. 2010). Karnieli et al. (2007) demonstrated that PDX1 induces a profound change in gene expression in human bone marrow MSCs cultured in vitro and can drive its differentiation toward the $\beta$-cell phenotype.

\section{Differentiation of Adipose Derived Stem Cells}

Adipose tissue is a easily accessible and abundant source of MSCs (Rodriguez et al. 2005; Zuk et al. 2002). Timper et al. (2006) noticed that human adipose derived stem cells 
(ADSCs) are able to adopt a pancreatic endocrine cell phenotype ex vivo. ADSCs were induced to differentiate into an insulin-producing cells by defined culture conditions within 3 days. Every $24 \mathrm{~h}$ of three-day differentiation procedure expression of ABCG2 (stem cell marker), IPF-1, ISL-1, NGN3, PAX-6 and islet hormones was analyzed. ABCG2 and PAX-6 expression was found in proliferating MSCs. Expression of ABCG2 was decreased and PAX-6 was no induced by the 3 days differentiation procedure. Upregulation of pancreatic transcription factors IPF-1, ISL-1, NGN3 and islet hormones was observed during the differentiation period (Timper et al. 2006). Chandra (2009) demonstrated three-step differentiation protocol of IPCs from murine epididymal adipose stem cells (mE-ASCs). The mE-ASCs were first converted into definitive endoderm (activin-A, sodium butyrate, $\beta$-mercaptoethanol), then into pancreatic endoderm (taurine) and finally into pancreatic hormone-expressing islet-like cell aggregates (ICAs) (taurine, GLP-1, nicotinamide, NEAA). After 10 days ICAs showed positive staining for ditizone (zincchelating agent known to selectively stain pancreatic $\beta$ cells) and coexpressed insulin, glucagon and somatostatin. Moreover, matured ICAs exhibited expression of Pdx-1, C-peptide, insulin, glucagon, somatostatin, pancreatic polypeptide and Glut-2. ICAs transplantation in streptozotocine induced diabetic mice restored normoglycemia within 2 weeks (Chandra 2009). Similar three-step differentiation protocol was able to differentiate the human adipose tissue-derived stem cells into IPCs (Chandra et al. 2011). Kajiyama et al. (2010) reported that $P D X-1$ transfected adipose tissue-derived stem cell can differentiate into insulin-producing cells. The human $P D X-1$ gene was integrated with retrovirus and transducted into ADSCs. Transplantation of PDX-1 transduced ADSCs into streptozotocine-induced diabetic mice reduced the blood glucose levels. In this study $25 \%$ of the PDX-1-ADSCs transplanted into pancreas of the streptozotocine treated mice differentiated into insulin-producing cells (Kajiyama et al. 2010).

\section{Differentiation of Other Types of MSCs}

Chao et al. reported that human MSCs-derived from Wharton's jelly of the umbilical cord can differentiate into islet-like clusters through stepwise culturing in neuronconditioned medium. These islet-like clusters showed the enhancement of insulin expression and pancreatic $\beta$-cellrelated genes, such as $P d x 1, H l x b 9, N k x 2.2, N k x 6.1$, and Glut-2. They released insulin in response to glucose stimulation in vitro and reduced hyperglycemia in streptozocininduced diabetic rats in vivo (Chao et al. 2008). More recently, Kim et al. (2012) generated insulin-producing cells from MSCs derived from periosteum (periosteum derived progenitor cells). Cells were cultured for 2-3 weeks in high glucose level medium containing: nicotinamide, activin-A, extendin-4, HGF, B27 and N2 supplements. Periosteum-derived IPCs expressed genes characteristic for $\beta$-cell development and responded to glucose stimulation (Kim et al. 2012). Another authors indicated that also endometrial MSCs can differentiate into functional insulin-producing cells (Chang et al. 2007; Li et al. 2010). Zanini et al. (2011) reported the ability of human pancreatic islet-derived mesenchymal cells to differentiate into pancreatic endocrine phenotype. Pancreasderived MSCs cultured for 21 days in a medium for endocrine differentiation formed clusters that acquiring an islet-like morphology and secreted insulin in response to glucose stimulation (Zanini et al. 2011). Eberhardt et al. (2006) isolated nestin-positive MSCs from human pancreatic islets and immortalized them with lentiviral vectors coding telomerase and $\mathrm{mBmi}$. Immortalized cells were differentiated into islet-like clusters. Differentiated cells expressed genes ISL-1, IPF-1, NGN3, PAX4, PAX6, $N K X 2.2$ and NKX6.1 as well as islet hormones insulin, glucagon and somatostatin, related to pancreatic $\beta$-cell development (Eberhardt et al. 2006). They indicated that IPCs obtained from islet-derived MSCs are able to go further along the endocrine pathway comparing with those originated from BM-MSCs.

Several studies demonstrated the role of extracellular matrix proteins in IPCs differentiation. It was indicated that $\mathrm{FN}$ and LAM affected $\beta$-cell differentiation, proliferation, and insulin secretion. These proteins enhanced pancreatic differentiation from MSCs: stimulated insulin and GLUT2 gene expressions, increased proinsulin and insulin protein levels. Moreover they enhanced insulin secretion in response to glucose stimulation and accumulation of insulin granules in IPCs (Table 3) (Lin et al. 2010). Gao et al. (2008) have indicated that extracellular matrix gel plays an important role not only in differentiation of human umbilical cord blood derived MSCs into IPCs, but also in maturation and formation of three dimensional structures. This observations were confirmed by other authors (Chang et al. 2008).

Based on the quoted studies it can be concluded that MSCs are able to differentiate into insulin-producing cells. Many types of differentiation protocols have been developed, which ultimately led to achieve the desired results confirming the presented theory (Gao et al. 2008; Lin et al. 2010; Oh et al. 2004).

\section{Differentiation of Progenitor Cells}

Hori et al. reported that brain-derived human neural progenitor cells are able to differentiate into insulin-positive 
cells. They indicated that human neural stem cells have a broad differentiation potential and that specific in vitro culture conditions can differentiate them into insulin-producing cells (Hori et al. 2005). Molecular analysis of differentiated IPCs showed that they remain distinct from mature pancreatic islet $\beta$ cells. Differentiated cells expressed declined level of NGN3, increased or maintained levels of ISL-1, FOXA3, and PDX1 and very low level of insulin (Hori et al. 2005). Another study indicated that progenitor cells-derived from adult human pancreatic ducts (CK19-positive ductal epithelial cells) are able to differentiate into insulin-producing ones. An in vitro-generated islet buds released insulin in response to glucose nearly as efficiently as native islets. Although, when transplanted under the kidney capsule of nude mice, only one of five grafts demonstrated further growth with foci of both endocrine and exocrine differentiation (Gao et al. 2003). Liver stem/progenitor cells are self-renewing capability and multilineage differentiation potential (Suzuki et al. 2002). Feng et al. (2005) indicated that these cells could be converted into insulin-producing cells under specific culture condition (medium supplemented with nicotinamide, L-glutamine, $\beta$-mercaptoethanol and glucose). When these cells were transplanted into alloxan-induced diabetic mice, the non-fasting blood glucose level was reduced (Feng et al. 2005).

\section{Remaining Challenges and Conclusions}

A number of challenges need to be overcome before based on insulin-producing cell therapy will be utilized for diabetes treatment. One of the major problem to overcome is full maturation of IPCs in vitro. Differentiated cells secrete very low level of insulin, express multiple hormones and show very little response to glucose stimulation. A possible explanation for $\beta$ cells maturation failure in vitro could be absence of mesenchyma-epithelium interactions, that occur during pancreatic embryogenesis (Kumar et al. 2003). Another challenge is long term survival of IPCs grafts. Immature IPCs transplanted extra-pancreatically could dedifferentiate or even switch to another cell types. Murine and human stem cells as well as pancreatic islets are dissimilar in many aspects, therefore translation of research evidences from animal to human requires extreme caution. Although there are strong evidences which confirm that generated in vitro IPCs reduce hyperglycemia in rodent, the capability of IPCs to treat diabetic patients is still nebulous. Generation of IPCs in large scale, realistic for clinical application is another hurdle.

IPCs obtained from autologous cells of patient with DM1 and transplanted back could be targeted by immune system. Therefore, the challenge for a successful cell based therapy in DM1 treatment is not only the functional $\beta$ cells generation but also blocking the autoimmune response. Even though significant challenges remains, there are many reasons to believe that $\beta$-cell replacement therapy may became a clinical reality for the treatment of patients with DM.

Conflict of interest The authors declare no potential conflicts of interest.

\section{References}

Aasen T, Raya A, Barrero MJ et al (2008) Efficient and rapid generation of induced pluripotent stem cells from human keratinocytes. Nat Biotechnol 26:1276-1284

American Diabetes Association (2011) Diagnosis and classification of diabetes mellitus. Diabetes Care 34:S62-S69

Artner I, Le Lay J, Hang Y et al (2006) MafB: an activator of the glucagon gene expressed in developing islet alpha- and beta-cells. Diabetes 55:297-304

Artner I, Hang Y, Mazur M et al (2010) MafA and MafB regulate genes critical to beta-cells in a unique temporal manner. Diabetes 59:2530-2539

Baeyens L, De Breuck S, Lardon J et al (2005) In vitro generation of insulin producing beta cells from adult exocrine pancreatic cells. Diabetologia 48:49-57

Bai L, Meredith G, Tuch BE (2005) Glucagon-like peptide-1 enhances production of insulin in insulin-producing cells derived from mouse embryonic stem cells. J Endocrinol 186:343-352

Bernardo AS, Cho CH, Mason S et al (2009) Biphasic induction of $\mathrm{Pdx} 1$ in mouse and human embryonic stem cells can mimic development of pancreatic beta-cells. Stem Cells 27:341-351

Blyszczuk P, Czyz J, Kania G et al (2003) Expression of Pax4 in embryonic stem cells promotes differentiation of nestin-positive progenitor and insulin-producing cells. Proc Natl Acad Sci USA 100:998-1003

Blyszczuk P, Asbrand C, Rozzo A (2004) Embryonic stem cells differentiate into insulin-producing cells without selection of nestin-expressing cells. Int J Dev Biol 48:1095-1104

Borowiak M, Maehr R, Chen S (2009) Small molecules efficiently direct endodermal differentiation of mouse and human embryonic stem cells. Cell Stem Cell 4:348-358

Boyd AS, Wu DC, Higashi Y et al (2008) A comparison of protocols used to generate insulin-producing cell clusters from mouse embryonic stem cells. Stem Cells 26:1128-1137

Cai W, Zhang Y, Kamp TJ (2011) Imaging of induced pluripotent stem cells: from cellular reprogramming to transplantation. Am J Nucl Med Mol Imaging 1:18-28

Carlotti F, Zaldumbide A, Loomans CJ et al (2010) Isolated human islets contain a distinct population of mesenchymal stem cells. Islets 2:164-173

Chandra V, S G, Phadnis S, Nair PD et al (2009) Generation of pancreatic hormone-expressing islet-like cell aggregates from murine adipose tissue-derived stem cells. Stem Cells 27:19411953

Chandra V, Swetha G, Muthyala S et al (2011) Islet-like cell aggregates generated from human adipose tissue derived stem cells ameliorate experimental diabetes in mice. PLoS One 6:e20615

Chang CM, Kao CL, Chang YL et al (2007) Placenta-derived multipotent stem cells induced to differentiate into insulinpositive cells. Biochem Biophys Res Commun 357:414-420 
Chang CF, Hsu KH, Chiou SH et al (2008) Fibronectin and pellet suspension culture promote differentiation of human mesenchymal stem cells into insulin producing cells. J Biomed Mater Res A 86:1097-1105

Chao KC, Chao KF, Fu YS et al (2008) Islet-like clusters derived from mesenchymal stem cells in Wharton's Jelly of the human umbilical cord for transplantation to control type 1 diabetes. PLoS One 3:e1451

Chen LB, Jiang XB, Yang L (2004) Differentiation of rat marrow mesenchymal stem cells into pancreatic islet beta-cells. World J Gastroenterol 10:3016-3020

Cho YM, Lim JM, Yoo DH et al (2008) Betacellulin and nicotinamide sustain PDX1 expression and induce pancreatic beta-cell differentiation in human embryonic stem cells. Biochem Biophys Res Commun 366:129-134

Collombat P, Hecksher-Sørensen J, Broccoli V et al (2005) The simultaneous loss of Arx and Pax4 genes promotes a somatostatin- producing cell fate specification at the expense of the alpha- and beta-cell lineages in the mouse endocrine pancreas. Development 132:2969-2980

D'Amour KA, Bang AG, Eliazer S et al (2006) Production of pancreatic hormone-expressing endocrine cells from human embryonic stem cells. Nat Biotechnol 24:1392-1401

Degn KB, Brock B, Juhl CB et al (2004) Effect of intravenous infusion of exenatide (synthetic exendin-4) on glucosedependent insulin secretion and counterregulation during hypoglycemia. Diabetes 53:2397-2403

Ding DC, Shy WC, Lin SZ (2011) Mesenchymal stem cells. Cell Transplant 20:5-14

Dor Y, Brown J, Martinez OI et al (2004) Adult pancreatic beta-cells are formed by self-duplication rather than stem-cell differentiation. Nature 429:41-46

Eberhardt M, Salmon P, von Mach MA et al (2006) Multipotential nestin and Isl-1 positive mesenchymal stem cells isolated from human pancreatic islets. Biochem Biophys Res Commun 345:1167-1176

Elghazi L, Cras-Meneur C, Czernichow P et al (2002) Role for FGFR2IIIb-mediated signals in controlling pancreatic endocrine progenitor cell proliferation. Proc Natl Acad Sci USA 99:3884-3889

Feng RQ, Du LY, Guo ZQ (2005) In vitro cultivation and differentiation of fetal liver stem cells from mice. Cell Res 15:401-405

Gao R, Ustinov J, Pulkkinen MA et al (2003) Characterization of endocrine progenitor cells and critical factors for their differentiation in human adult pancreatic cell culture. Diabetes 52:2007-2015

Gao F, Wu DQ, Hu YH et al (2008) Extracellular matrix gel is necessary for in vitro cultivation of insulin producing cells from human umbilical cord blood derived mesenchymal stem cells. Chin Med J 121:811-818

Gittes GK (2009) Developmental biology of the pancreas: a comprehensive review. Dev Biol 326:4-35

Gu G, Dubauskaite J, Melton DA (2002) Direct evidence for the pancreatic lineage: NGN3ţ cells are islet progenitors and are distinct from duct progenitors. Development 129:2447-2457

Guo T, Hebrok M (2009) Stem cells to pancreatic beta-cells: new sources for diabetes cell therapy. Endocr Rev 30:214-227

Habener JF, Kemp DM, Thomas MK (2005) Minireview: transcriptional regulation in pancreatic development. Endocrinology 146:1025-1034

Hardikar AA, Wang XY, Williams L et al (2002) Functional maturation of fetal porcine beta cells by glucagon-like peptide 1 and cholecystokinin. Endocrinology 143:3505-3514

Henseleit KD, Nelson SB, Kuhlbrodt K et al (2005) NKX6 transcription factor activity is required for alpha- and beta-cell development in the pancreas. Development 132:3139-3149
Hisanaga E, Park KY, Yamada S et al (2008) A simple method to induce differentiation of murine bone marrow mesenchymal cells to insulin-producing cells using conophylline and betacellulin-delta 4. Endocr J 55:535-543

Hori Y, Rulifson IC, Tsai BC et al (2002) Growth inhibitors promote differentiation of insulin-producing tissue from embryonic stem cells. Proc Natl Acad Sci USA 99:16105-16110

Hori Y, Gu X, Xie X et al (2005) Differentiation of insulin-producing cells from human neural progenitor cells. PLoS Med 2:e103

Huangfu D, Maehr R, Guo W et al (2008) Induction of pluripotent stem cells by defined factors is greatly improved by smallmolecule compounds. Nat Biotechnol 26:795-797

Hui H, Perfetti R (2002) Pancreas duodenum homeobox-1 regulates pancreas development during embryogenesis and islet cell function in adulthood. Eur J Endocrinol 146:129-141

Jiang W, Shi Y, Zhao D et al (2007a) In vitro derivation of functional insulin-producing cells from human embryonic stem cells. Cell Res 17:333-344

Jiang J, Au M, Lu K et al (2007b) Generation of insulin-producing islet-like clusters from human embryonic stem cells. Stem Cells 25:1940-1953

Johansson KA, Dursun U, Jordan N et al (2007) Temporal control of neurogenin 3 activity in pancreas progenitors reveals competence windows for the generation of different endocrine cell types. Dev Cell 12:457-465

Kaji K, Norrby K, Paca A et al (2009) Virus-free induction of pluripotency and subsequent excision of reprogramming factors. Nature 458:771-775

Kajiyama H, Hamazaki TS, Tokuhara M et al (2010) Pdx1-transfected adipose tissue-derived stem cells differentiate into insulinproducing cells in vivo and reduce hyperglycemia in diabetic mice. Int J Dev Biol 54:699-705

Karnieli O, Izhar-Prato Y, Bulvik S et al (2007) Generation of insulinproducing cells from human bone marrow mesenchymal stem cells by genetic manipulation. Stem Cells 25:2837-2844

Kataoka K, Han SI, Shioda S et al (2002) MafA is a glucose-regulated and pancreatic beta-cell-specific transcriptional activator for the insulin gene. J Biol Chem 277:49903-49910

Kelly CM, Tyers P, Borg MT et al (2005) EGF and FGF-2 responsiveness of rat and mouse neural precursors derived from the embryonic CNS. Brain Res Bull 68:83-94

Kim JB, Greber B, Arauzo-Bravo MJ et al (2009) Direct reprogramming of human neural stem cells by OCT4. Nature 461: 649-653

Kim SJ, Choi YS, Ko ES et al (2012) Glucose-stimulated insulin secretion of various mesenchymal stem cells after insulinproducing cell differentiation. J Biosci Bioeng 113:771-777

Kroon E, Martinson LA, Kadoya K et al (2008) Pancreatic endoderm derived from human embryonic stem cells generates glucoseresponsive insulin-secreting cells in vivo. Nat Biotechnol 26:443-452

Kubo A, Stull R, Takeuchi $M$ et al (2011) Pdx1 and Ngn3 overexpression enhances pancreatic differentiation of mouse ES cell-derived endoderm population. PLoS One 6:e24058

Kumar M, Jordan N, Melton D et al (2003) Signals from lateral plate mesoderm instruct endoderm toward a pancreatic fate. Dev Biol 259:109-122

Kunisada Y, Tsubooka-Yamazoe N, Shoji M et al (2012) Small molecules induce efficient differentiation into insulin-producing cells from human induced pluripotent stem cells. Stem Cell Res $8: 274-284$

Lau J, Kawahira H, Hebrok M (2006) Hedgehog signaling in pancreas development and disease. Cell Mol Life Sci 63:642-652

Li L, Yi Z, Seno M et al (2004) Activin A and betacellulin: effect on regeneration of pancreatic beta-cells in neonatal streptozotocintreated rats. Diabetes 53:608-615 
Li HY, Chen YJ, Chen SJ et al (2010) Induction of insulin-producing cells derived from endometrial mesenchymal stem-like cells. J Pharmacol Exp Ther 335:817-829

Liang XD, Guo YY, Sun M et al (2011) Streptozotocin-induced expression of Ngn3 and Pax4 in neonatal rat pancreatic $\alpha$-cells. World J Gastroenterol 17:2812-2820

Lin HT, Kao CL, Lee KH et al (2007) Enhancement of insulinproducing cell differentiation from embryonic stem cells using pax4-nucleofection method. World J Gastroenterol 13:1672-1679

Lin HY, Tsai CC, Chen LL et al (2010) Fibronectin and laminin promote differentiation of human mesenchymal stem cells into insulin producing cells through activating Akt and ERK. J Biomed Sci 17:1-10

Loh YH, Agarwal S, Park IH et al (2009) Generation of induced pluripotent stem cells from human blood. Blood 113:5476-5479

Lorenzo PI, Jimenez Moreno CM, Delgado I et al (2011) Immunohistochemical assessment of Pax8 expression during pancreatic islet development and in human neuroendocrine tumors. Histochem Cell Biol 136:595-607

Lowry WE, Richter L, Yachechko R et al (2008) Generation of human induced pluripotent stem cells from dermal fibroblasts. Proc Natl Acad Sci USA 105:2883-2888

Lumelsky N, Blondel O, Laeng P et al (2001) Differentiation of embryonic stem cells to insulin-secreting structures similar to pancreatic islets. Science 292:1389-1394

May CL (2010) The role of Islet-1 in the endocrine pancreas: lessons from pancreas specific Islet-1 deficient mice. Islets 2:121-123

Noguchi H (2009) Pancreatic islet transplantation. World J Gastrointest Surg 1:16-20

Oh SH, Muzzonigro TM, Bae SH et al (2004) Adult bone marrowderived cells trans-differentiating into insulin-producing cells for the treatment of type I diabetes. Lab Invest 84:607-617

Oh YS, Shin S, Lee YJ et al (2011) Betacellulin-induced beta cell proliferation and regeneration is mediated by activation of ErbB1 and ErbB-2 receptors. PLoS ONE 6:e23894

Okita K, Ichisaka T, Yamanaka S (2007) Generation of germlinecompetent induced pluripotent stem cells. Nature 448:313-317

Okita K, Nakagawa M, Hyenjong H et al (2008) Generation of mouse induced pluripotent stem cells without viral vectors. Science 322:949-953

Park IH, Zhao R, West JA et al (2008) Reprogramming of human somatic cells to pluripotency with defined factors. Nature 451:141-146

Raslova K (2010) An update on the treatment of type 1 and type 2 diabetes mellitus: focus on insulin detemir, a long-acting human insulin analog. Vasc Health Risk Manag 6:399-410

Rodriguez AM, Elabd C, Amri EZ et al (2005) The human adipose tissue is a source of multipotent stem cells. Biochimie 87:125-128

Schwindt TT, Motta FL, Gabriela BF et al (2009) Effects of FGF-2 and EGF removal on the differentiation of mouse neural precursor cells. An Acad Bras Cienc 81:443-452

Shi Y, Hou L, Tang F et al (2005) Inducing embryonic stem cells to differentiate into pancreatic $\beta$-cells by a novel three-step approach with activin A and all-trans retinoic acid. Stem Cells 23:656-662

Shiroi A, Ueda S, Ouji Y et al (2005) Differentiation of embryonic stem cells into insulin-producing cells promoted by $N k x 2.2$ gene transfer. World J Gastroenterol 11:4161-4166

Soria B, Bedoya FJ, Martin F (2005) Gastrointestinal stem cells: I. Pancreatic stem cells. Am J Physiol Gastrointest Liver Physiol 289:G177-G180

Stadtfeld M, Nagaya M, Utikal J et al (2008) Induced pluripotent stem cells generated without viral integration. Science 322:945-949

Stafford D, Prince VE (2002) Retinoic acid signaling is required for a critical early step in Zebrafish pancreatic development. Curr Biol 12:1215-1220
Stafford D, Hornbruch A, Mueller PR et al (2004) A conserved role for retinoid signaling in vertebrate pancreas development. Dev Genes Evol 214:432-441

Sun Y, Chen L, Hou XG et al (2007) Differentiation of bone marrowderived mesenchymal stem cells from diabetic patients into insulin-producing cells in vitro. Chin Med J 120:771-776

Suzuki A, Zheng YW, Kaneko S et al (2002) Clonal identification and characterization of self-renewing pluripotent stem cells in the developing liver. J Cell Biol 156:173-184

Takahashi K, Tanabe K, Ohnuki M et al (2007) Induction of pluripotent stem cells from adult human fibroblasts by defined factors. Cell 131:861-872

Takenaga M, Fukumoto M, Hori Y (2007) Regulated Nodal signaling promotes differentiation of the definitive endoderm and mesoderm from ES cells. J Cell Sci 120:2078-2090

Tang DQ, Cao LZ, Burkhardt BR et al (2004) In vivo and in vitro characterization of insulin-producing cells obtained from murine bone marrow. Diabetes 53:1721-1732

Tateishi K, He J, Taranova O et al (2008) Generation of insulinsecreting islet-like clusters from human skin fibroblasts. J Biol Chem 283:31601-31607

Timper K, Seboek D, Eberhardt M et al (2006) Human adipose tissuederived mesenchymal stem cells differentiate into insulin, somatostatin, and glucagon expressing cells. Biochem Biophys Res Commun 341:1135-1140

Tureyen K, Vemuganti R, Bowen KK et al (2005) EGF and FGF-2 infusion increases post-ischemic neural progenitor cell proliferation in the adult rat brain. Neurosurgery 57:1254-1263

Wang R, Yashpal N, Bacchus F et al (2004) Hepatocyte growth factor regulates proliferation and differentiation of epithelial monolayers derived from islets of postnatal rat pancreas. J Endocrinol 183:163-171

Wang PX, Yu ZW, Wong S et al (2011) Nkx6.2 synergizes with Cdx2 in stimulating proglucagon gene expression. World J Diabetes 2:66-74

Wilson ME, Scheel D, German MS (2003) Gene expression cascades in pancreatic development. Mech Dev 120:65-80

Wobus AM, Boheler KR (2005) Embryonic stem cells: prospects for developmental biology and cell therapy. Physiol Rev 85:635-678

Woltjen K, Michael IP, Mohseni P et al (2009) PiggyBac transposition reprograms fibroblasts to induced pluripotent stem cells. Nature 458:766-770

Yu J, Vodyanik MA, Smuga-Otto K et al (2007) Induced pluripotent stem cell lines derived from human somatic cells. Science 318:1917-1920

Yu J, Hu K, Smuga-Otto K et al (2009) Human induced pluripotent stem cells free of vector and transgene sequences. Science 324:797-801

Zanini C, Bruno S, Mandili G et al (2011) Differentiation of mesenchymal stem cells derived from pancreatic islets and bone marrow into islet-like cell phenotype. PLoS One 6:e28175

Zhang D, Jiang W, Liu M et al (2009a) Highly efficient differentiation of human ES cells and iPS cells into mature pancreatic insulinproducing cells. Cell Res 19:29-438

Zhang YH, Wang HF, Liu W (2009b) Insulin-producing cells derived from rat bone marrow and their autologous transplantation in the duodenal wall for treating diabetes. Anat Rec (Hoboken) 292:728-735

Zhang Y, Shen W, Hua J et al (2010) Pancreatic islet-like clusters from bone marrow mesenchymal stem cells of human firsttrimester abortus can cure streptozocin-induced mouse diabetes. Rejuvenation Res 13:695-706

Zhou H, Wu S, Joo JY et al (2009) Generation of induced pluripotent stem cells using recombinant proteins. Cell Stem Cell 4:381-384

Zuk PA, Zhu M, Ashjian P et al (2002) Human adipose tissue is a source of multipotent stem cells. Mol Biol Cell 13:4279-4295 